\title{
PERIKANAN PELAGIS KECIL DI DAERAH TELUK: STUDI KASUS DI TELUK SAPE NUSA TENGGARA BARAT
}

\author{
SMALL PELAGIC FISHERIES IN BAY AREA: \\ A CASE STUDY AT SAPE BAY WEST NUSA TENGGARA
}

\author{
$\mathrm{Suadi}{ }^{*}$
}

\begin{abstract}
The aims of this research were to know the state of small pelagic fishery and social economic aspect of resources exploitation. To examine these issues, the research combined survey and descriptive analytic methods. Gordon-Schaefer model was applied to analyze the state of fishery and analytical descriptive to explained the relationship of the phenomena's. Data collection was based on indepth interview and recording of District Fishery Service's. Samll pelagic fisheries that been analyzed were anchovies (Stolephorus sp.), squids (Loligo $\mathrm{sp}$.), and mackerels (Rastrelliger sp.).

There are two main problems of fisheries in the area, firstly, the conflict on coastal zone between marine capture fisheries and mariculture. The second one is the intensive exploitation of fisheries resources. Pelagic fisheries at Sape Bay have been exploited above maximum TAC mainly $80 \%$ of MSY. MSY of anchovies (Stolephorus sp.) reached 2324,9 ton at number of effort 56534 trip and MEY 2172,3 ton at number of effort 42144 trips. MSY of squids (Loligo sp.) is 455,0 ton at number of effort 12183 trip and MEY 449,0 ton at number of effort 10780 trips equal to Bagan Perahu trips. The model was not applicable to predict the MSY and MEY of mackerels (Rastrelliger sp.). The continuing increase of effort will depleted the stock and decreased economic rent. In addition, the increasing of competition on fishing ground with pearl culture, have resulted fishermen stress. The integrated policy and management are needed to solve these problems and to avoid social riots.
\end{abstract}

Key words: MSY, MEY, small pelagic fisheries, and social problems

\section{Pengantar}

Pemanfaatan sumberdaya ikan pelagis kecil di pelbagai perairan menunjukkan tingkat eksploitasi yang intensif (Cruz dan Trinidad, 1993; Nurhakim dkk., 1994). Sumberdaya ikan ini telah memberikan kontribusi terhadap produksi dan ekonomi yang cukup besar bagi nelayan. Kebijakan pemanfaatan sumberdaya ke Kawasan Timur Indonesia dan motorisasi perikanan tangkap yang semakin meningkat akan mendorong eksploitasi sumberdaya yang berlebihan, sehingga mengancam kelestarian sumberdaya ikan. $\mathrm{Di}$ samping itu, juga terdapat

\footnotetext{
*) Staf Pengajar Jurusan Perikanan UGM

E-mail: suadi@faperta.ugm.ac.id
}

kecenderungan usaha perikanan budidaya laut berkembang pesat di wilayah tersebut. Kontribusi yang cukup positif bagi peningkatan ekpor komoditas non migas dan pendapatan daerah, mendorong pemerintah daerah untuk merencanakan pengembangan lebih luas budidaya laut khususnya budidaya mutiara. Kontribusi budidaya mutiara bagi ekpor komoditi non migas di di Kabupaten Bima merupakan yang terbesar. Penelitian ini bertujuan untuk mengetahui potensi, status dan sosial-ekonomi pemanfaatan sumberdaya ikan pelagis kecil di Teluk Sape, Kabupaten Bima, Nusa Tenggara Barat. 


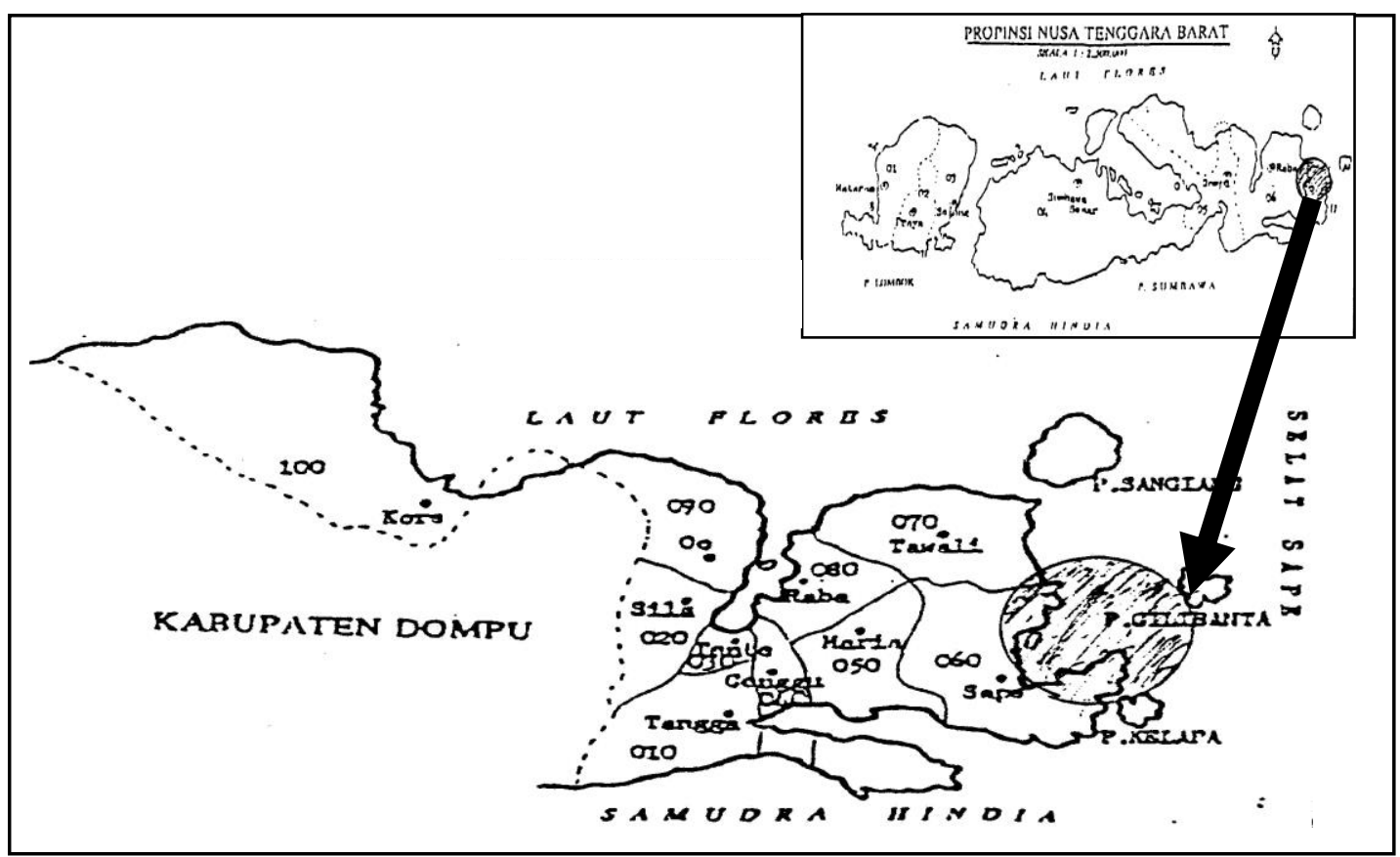

Gambar 1. Lokasi Penelitian di Teluk Sape Kabupaten Bima Nusa Tenggara Barat
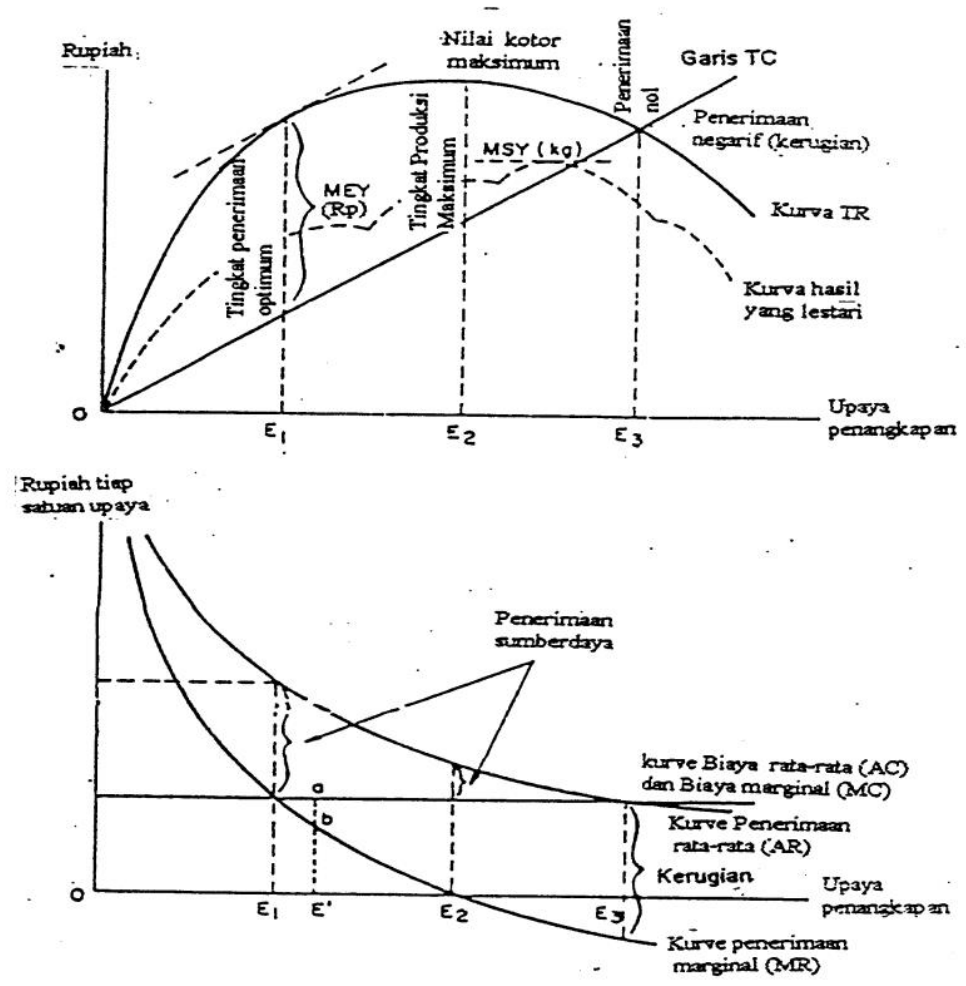

Gambar 2. Konsep Bio-Ekonomi Pengelolaan Sumberdaya Ikan (Panayatou 1992) 


\section{Bahan dan Metode}

\section{Lokasi penelitian}

Penelitian dilakukan di daerah sekitar Teluk Sape, Kabupaten Bima, NTB. Secara geografis, daerah penelitian terletak di sekitar perairan Selat Sape yang menghubungkan propinsi NTB dan NTT, pada lintang $114^{\circ} 40^{\prime}$ dan $119^{\circ} 45^{\prime}$ bujur timur dan $8^{0} 51^{\prime}$ lintang selatan (Gambar 1).

\section{Pengumpulan data}

Penelitian menggunakan perpaduan metode survey dan deskriptif analitik. Pengumpulan data dilakukan dengan teknik pencatatan dan indepth interview dari nelayan sampel, instansi dan pejabat terkait. Sampel nelayan berjumlah 40 orang yang dipilih secara proporsional berdasarkan jenis alat tangkap. Data meliputi 1) produksi dan sarana penangkapan ikan pelagis kecil, 2) harga ikan dan biaya produksi, dan 3) aspek sosial-ekonomi pemanfatan sumberdaya perairan di daerah teluk.

\section{Analisis data}

Data biologi dan ekonomi perikanan pelagis kecil dianalisis dengan pendekatan bio-ekonomi model statik dari GordonSchafer (Clark, 1985; Widodo, 1986; Purwanto, 1988). Sedangkan permasalahan sosial-ekonomi dalam pengelolaan dan pemanfaatan sumberdaya ikan pelagis kecil dianalisis secara deskriptif (Nazir 1988).

\section{Hasil dan Pembahasan}

\section{Potensi dan status sumberdaya ikan}

Kegiatan perikanan tangkap di sekitar teluk dan Selat Sape menjadi prioritas pengembangan wilayah timur Kabupaten Bima (Anonim, 1997). Hal ini didorong oleh kontribusi kegiatan perikanan tangkap yang cukup besar bagi Kabupaten Bima, khusus perikanan pelagis kecil. Perikanan ini di NTB secara umum memberikan kontribusi mencapai 59\% (34.000 ton) dengan total nilai Rp 15,3 milyar (Nugroho dkk. 1992). Di teluk dan sekitar Selat Sape, $60 \%$ total produksi ikan laut disumbang oleh perikanan pelagis kecil dengan total produksi mencapai 19,5 ton pada tahun 1996.

Namun demikian, Kegiatan perikanan pelagis kecil di daerah teluk tidak berbeda dengan daerah-daerah lainya seperti di laut Jawa yang telah mengalami eksploitasi berlebihan (Nurhakim, dkk. 1994). Jenis ikan pelagis kecil yang tertangkap umumnya ikan ekonomis penting seperti seperti teri (Stolephorus sp.), kembung (Rastrelliger sp.) dan cumi (Loligo sp.). Ikan teri dan cumi-cumi yang merupakan ikan sasaran utama, khususnya untuk alat tangkap dominan di daerah tersebut, yaitu bagan perahu. Produksi ikan tersebut sangat fluktuatif. Pada tahun 1990-1992 produksi ikan teri menurun dan meningkat kembali pada tahun berikutnya sampai tahun 1995 . Produksi cumi-cumi turun pada tahun 1989-1991 dan meningkat kembali pada tahun 1992-1993, kemudian kembali dan turun pada tahun 1995 dan tahun berikutnya. Keadaan yang sama juga terjadi pada ikan kembung. Gelombang tsunami sekitar tahun 1994 cukup berpengaruh terhadap produksi ikan.

Analisis stok ikan teri memiliki persamaan linier $C / f=82,7684 \quad-0,0007414 f \quad(r=-$ 0,31). Potensi lestari (MSY) berdasarkan persamaan tersebut adalah sebesar $2.324,89$ ton per tahun dengan upaya optimum mencapai 56534 trip atau sama dengan 276 unit alat setara bagan perahu. Tingkat eksploitasi sumberdaya telah mencapai 95,92\%. Penangkapan yang terus berlanjut dengan intensitas yang tinggi karena berbagai tuntutan sosial ekonomi nelayan akan mengantarkan pada situasi dimana nelayan tidak memperoleh keuntungan. Keadaan ini tercapai pada tingkat upaya 84288 trip atau sama dengan 411 unit alat setara bagan perahu. Tingkat keuntungan ekonomi optimum akan dapat dicapai jika 
upaya penangkapan hanya dilakukan pada tingkat pengusahaan yang mencapai 42144 trip per tahun atau setara dengan 206 unit alat setara bagan perahu.

Hasil analisis linier sederhana antara hasil tangkapan dan upaya untuk cumi-cumi diperoleh persamaan $\mathrm{C} / \mathrm{f}=74,6961$ $0,003066 f(r=-0,51)$. Dibandingkan dengan hasil penelitian yang dilakukan oleh Iskandar dkk. (1992) ternyata eksploitasi cumi-cumi beberapa tahun terakhir semakin intensif dilakukan. Hal ini ditunjukkan oleh kooefisien korelasi yang meningkat dari $r=-0,042$ menjadi $r=-$ 0,51 . Potensi lestari cumi-cumi dari persamaan tersebut adalah 454,9918 ton per tahun dengan total upaya 12183 trip per tahun setara dengan 150 unit bagan perahu. Tingkat eksploitasi cumi-cumi telah mencapai $84,42 \%$. Peningkatan upaya penangkapan cumi-cumi hanya dapat dilakukan pada tingkat keuntungan sama dengan nol, yaitu pada tingkat upaya 21561 trip atau sama dengan 221 unit alat setara bagan perahu. Keuntungan ekonomi optimum dicapai jika upaya pemanfaatan pada tingkat upaya 10780 trip per tahun atau setara 133 unit bagan perahu.

Penggunaan model Gordon-Schaefer untuk analisis stok ikan kembung belum dapat dilakukan karena syarat analisis dengan model surplus produksi yaitu koofisien korelasi negatif atau CPUE yang menurun dengan bertambahnya upaya tidak terpenuhi. Persamaan regresi untuk ikan kembung $C / f=-123,2727+0,02164 f$ $(r=0,52)$. Data tersebut memberikan gambaran bahwa pengembangan pemanfaatan spesies ini masih dapat dilakukan, namun peningkatan upaya tersebut perlu terus dipantau.

Keadaan perikanan seperti diuraikan di atas mengambarkan peningkatan intensitas penangkapan ikan telah mempengaruhi ketersediaan stok ikan. Menghadapi hasil tangkapan yang semakin berkurang dan berbagai bentuk konflik terhadap sumberdaya di sekitar teluk mendorong nelayan untuk melakukan berbagai bentuk strategi adaptasi, salah satunya adalah perluasan daerah penangkapan. Perluasan daerah ini bahkan telah mencapai propinsi Irian Jaya dan Sulawesi Utara serta daerah-daerah pantai di bagian barat propinsi NTT. Perluasan daerah penangkapan baru juga dilakukan pada daerah teluk sekitar Kabupaten Bima seperti Teluk Waworada, yaitu teluk yang berhadapan langsung dengan Samudra Hindia di bagian selatan Kabupaten Bima. Upaya ini sangat bermanfaat untuk meningkatkan hasil dan memberikan kesempatan pada sumberdaya ikan di daerah teluk untuk pulih.

\section{Konflik Antar Sektor Perikanan di Daerah Teluk}

Beberapa tahun terakhir usaha budidaya laut berkembang cukup pesat, bahkan meningkat $100 \%$ pada tahun 1992 , yaitu dari tiga perusahaan menjadi enam perusahaan (BPP Kecamatan Sape 1996). Pemerintah daerah melalui Dinas Perikanan pada tahun 1997 telah merencanakan pengembangan dan penempatan beberapa perusahaan baru, khususnya budidaya mutiara. Usaha ini mendapat prioritas karena sumbangannya terhadap ekonomi daerah yang cukup tinggi. Nilai ekspor produk mutiara mencapai Rp. 2.37 milyar atau yang terbesar dari ekspor non migas Kabupaten Bima (Anonim 1997).

Perkembangan budidaya mutiara di Teluk Sape yang semakin meningkat selain memberikan keuntungan ekonomi bagi daerah, juga meninggalkan permasalahan penting bagi nelayan. Dua permasalahan utama yang dihadapi oleh nelayan, yaitu pertama nelayan kehilangan So Rowa Oha (periuk nasi) atau daerah penangkapan utama, dan kedua nelayan kehilangan So Ruma Hawo atau tempat berlindung terutama pada musim gelombang besar dan atau angin kecang Dikatakan kehilangan so roa oha karena lokasi budidaya mutiara yang sama dengan fishing ground nelayan kecil, menyebabkan wilayah penangkapan menjadi berkurang. Daerah teluk tersebut 
juga merupakan daerah terlindung, karena pada musim barat ketika angin dan gelombang besar terjadi, mereka akan berlindung di daerah-daerah yang aman di dalam teluk yang kini juga menjadi wilayah utama kegiatan budidaya laut.

Prioritas yang besar pada budidaya mutiara oleh perusahaan skala besar tidak terlepas dari terminologi pembangunan ekonomi dengan pertumbuhan tinggi. Budidaya mutiara terbukti memberikan sumbangan yang besar, sehingga memberikan kontribusi yang tinggi bagi pertumbuhan ekonomi daerah. Di sisi lain, perikanan pelagis kecil di dominasi oleh sektor tradisional dalam skala kecil yang menurut Dapice (1980) dalam Betke (1988) merupakan usaha dengan investasi rendah dan hasil produksi yang kecil, yang menyebabkan kegiatan ini kurang diprioritaskan.

Belum jelasnya pengaturan tata ruang sumberdaya perairan di daerah teluk segera akan menjadi kerawanan sosial atau bahkan konflik dan kerusuhan sosial. Pengalaman kerusuhan sosial di hampir seluruh perairan Indonesia pada periode akhir 1970an sebagai akibat penggunaan pukat harimau tidak terlepas dari tidak jelasnya dan tidak berdayannya hukum dalam pengaturan tata ruang sumberdaya perairan. Hal ini akan mendorong terjadinya suatu tragedi sosial dalam masyarakat pesisir atau oleh Hardin (1964) disebut sebagai tragedi sumberdaya milik bersama (tragedy of the commons)

\section{Kesimpulan}

1. Perikanan pelagis kecil di Teluk Sape didominasi oleh usaha skala kecil dengan daerah penangkapan masih terbatas pada wilayah pantai/teluk. Usaha ini dihadapkan pada eksploitasi sumberdaya yang intensif dan konflik kepentingan terhadap sumberdaya perairan, khususnya dengan usaha budidaya laut.

2. Konflik kepentingan antar usaha perikanan khususnya budidaya laut dengan penangkapan perlu segera ditangani dan diperlukan tata ruang sumberdaya dan pemberdayaan hukum untuk menghindari terjadinya konflik dan kerusuhan sosial.

\section{Ucapan Terima Kasih}

Penulis mengucapkan terima kasih kepada Ir. Hery Saksono, Ir Supardjo SD, S.U., dan Ir. Retno Widaningroem, M.Sc. atas masukan bagi perbaikan tulisan ini dan pembimbingan selama kegiatan penelitian dilakukan.

\section{Daftar Pustaka}

Anonim. 1997. Laporan Akhir penyusunan Rencana Pengembangan Kawasan Andalan Kabupaten Bima Nusa Tenggara Barat. PT ayodya karya. Bima.

Betke, F. 1988. Prospects of Blue Revolution in Indonesian Fisheries: $A$ Bureaucratic Dream or Grim Reality (an Interpretation of Planned SocioEconomic Change in Contemporary Indonesia). Bieleferd. 216p. Unpublised

Clark, C.W. 1985. Bioeconomic Modelling and Fisheries Management. John Wiley and Sons. Canada. 291p.

Cruz, A. dan Trinidad. 1993. Economic Exploitation in the Philippine Small Pelagic Fishery and Implications for Management. Naga 16(4):13-15.

Hardin, G. 1964. The Tragedy of Commons. Science 162 (3855).

Iskandar, B., B. Sumiono, R. Basuki. 1992. Dugaan Potensi, Analisis Usaha, dan Prospek Pengembangan Sumberdaya Cumi-Cumi (Loligo spp.) di Selat Sape Nusa Tenggara. Jurnal Penelitian Perikanan Laut 66: 17-28 
Nasir, M. 1988. Metode Penelitian. Ghalia Indonesia. Jakarta. 264 p.

Nugroho, D., Edi M.A., Rusmadji. 1992. Tingkat Pemanfaatan Ikan Pelagis Kecil di Perairan Nusa Tenggara. Jurnal Penelitian Perikanan laut 66:9-16.

Nurhakim, S., B. Sadhotomo, M. Potier. Composite Model on Small Pelagic Resources dalam Biodynex: Biology, Dynamic, Exploitation of The Small Pelagic Fishes in The Java Sea. M. Potier dan S. Nurhakim (Ed). Pelfish. Jakarta. p:145-153.

Panayatou, T. 1992. Management Concepts for Small Scale Fisheries: Economic and Social Aspects. FAO Fisheries Technical Paper. Rome. 53p.

Purwanto.1988.Bio-Ekonomi Penangkapan Ikan: Model Statik. Oseana XIII(2):6372.

Widodo, Y. 1986. Surplus Production Models and Analysis of Exploted Population in Fisheries. Oseana XI(3):119-130. 